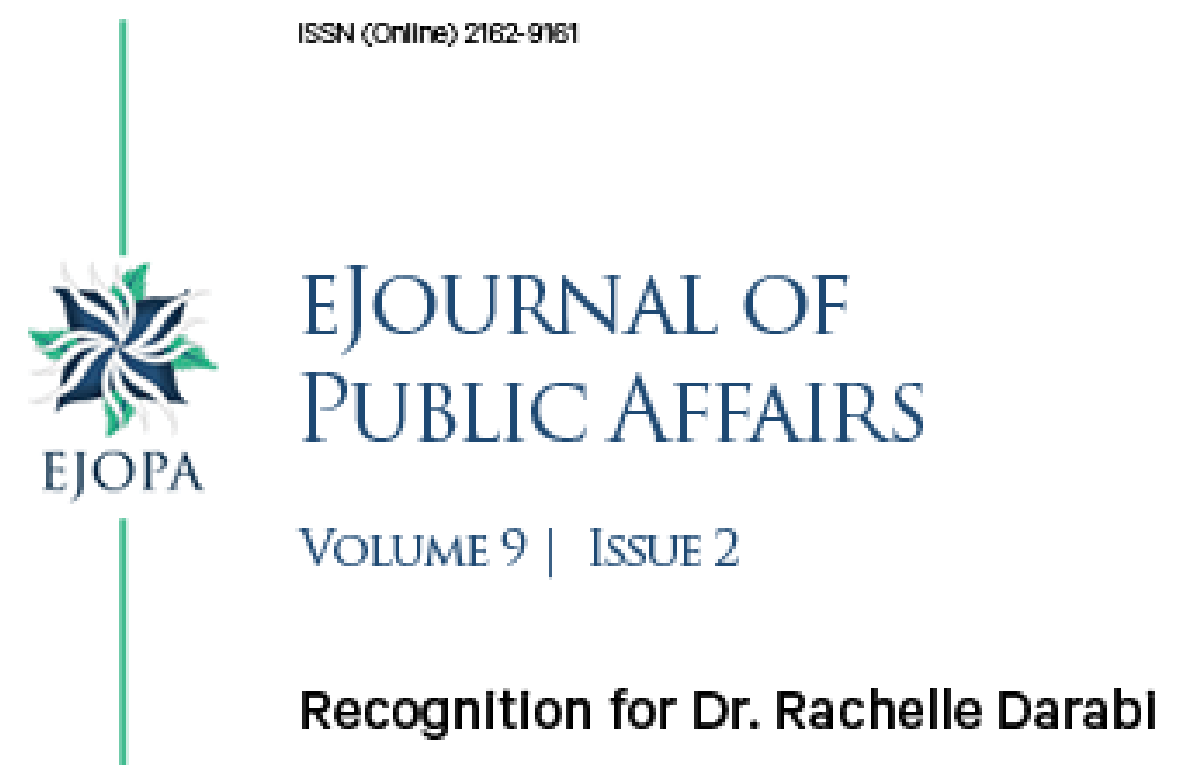

\author{
Andrew Lokle \\ Missouri State University \\ Kris Sutlliff \\ Missourl State University \\ Michael Frizell \\ Missourl State University
}


Andrew Lokie, Editor of eJournal of Public Affairs, Missouri State University

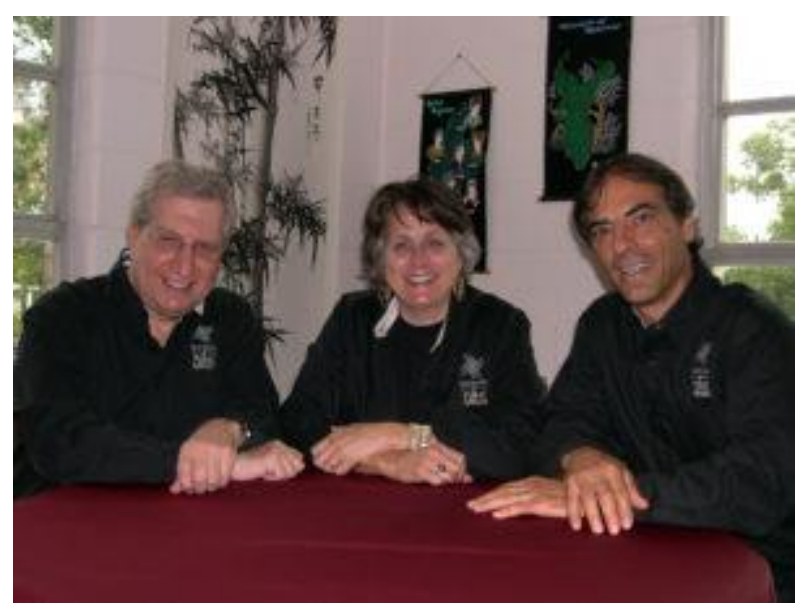

Figure 1: MARc CoOper, RAChelle DARABI, ANDREW LOKIE
As we progress down our career paths, we eventually approach a time to consider retirement, or should I say blissful retirement. My dear colleague Dr. Marc Cooper, who continued his work with the eJournal of Public Affairs as he celebrated his abbreviated retirement, would share our observations for how Dr. Rachelle Darabi was one of the best administrators/faculty members/and friend that we had the privilege to work with. It is important to realize her exceptional work, contributions, and the caring relationships and work environment that she facilitated in her capacity. As of the beginning of August 2020, Dr. Darabi officially retired from Missouri State University. To say that she is missed is an understatement. Fortunately, she has agreed to continue her service on EJOPA's Editorial Board.

This recognition includes a statement from one of Rachelle's colleagues and good friend, Dr. Kris Sutliff, who also worked with EJOPA. And a contribution from Michael Frizell, who was one of my colleagues working in the Student Development and Public Affairs department. The many directors who reported to her all have stories about their experience, leadership and her sincere passion for her work and convictions. For an idea for the scope of her work, the areas that she was responsible for were moved under four different reporting lines.

Along with the insights from Kris and Michael, perhaps the best way to exemplify what she's done can best be expressed by sharing her departing letter to the SDPA staff, her recent biography, and invite you to read her invited essay found in the editorials. It's difficult to adequately describe the significance of her approach and contributions. Having worked at four different higher-ed universities has provided me with the opportunity to witness the distinctions and commonalities across various institutions. In this, I have grown to better understand the impact between good and poor leadership. I will conclude by saying how much I have appreciated and enjoyed my work under the direction of Dr. Rachelle Darabi.

\section{Dear SDPA,}

As the saying goes, time flies. I can hardly believe it, but the days are few until I enter retirement after 32 years in higher-ed. The last 12 years here at MSU have been wonderful. I have so enjoyed working with all of you. We have so many things to be proud of like the creation of the Bear CLAW, Jump Start, Bear Breaks Immersion Program, Peace Corp Prep Program, the Bear Pantry, the Bachelor of General Studies, FCTL Bootcamps, First Gen initiatives, and the Center for Academic Success and Transition. In addition to these new initiatives, your work in SDPA has greatly enhanced Academic Advising, the Master Advisor Program, Transfer Advising, student retention initiatives, Service-Learning, faculty development, faculty curriculum grant 
offerings, diversity training for faculty, and all aspects of the Public Affairs mission through the conference, convocation, the Naturalization Ceremony, and more. Forgive me if I have missed some of the unit's accomplishments. They are so vast that it's hard to capture everything, but most important is the impact of your work. All of you have made Missouri State a stronger and better institution which has profound impact on our students. Because of all of you, tens of thousands of students have accomplished their goals. I have had the great honor of being a part of your amazing work, and I greatly appreciate my time with you at MSU. My only disappointment is that SDPA will no longer exist. However, under the new organizational structure, I know you all will excel and continue to collaborate with each other. Best wishes for a bright future to all of you.

Rachelle

Dr. Kris Sutliff, Professor Emeritus, Missouri State University

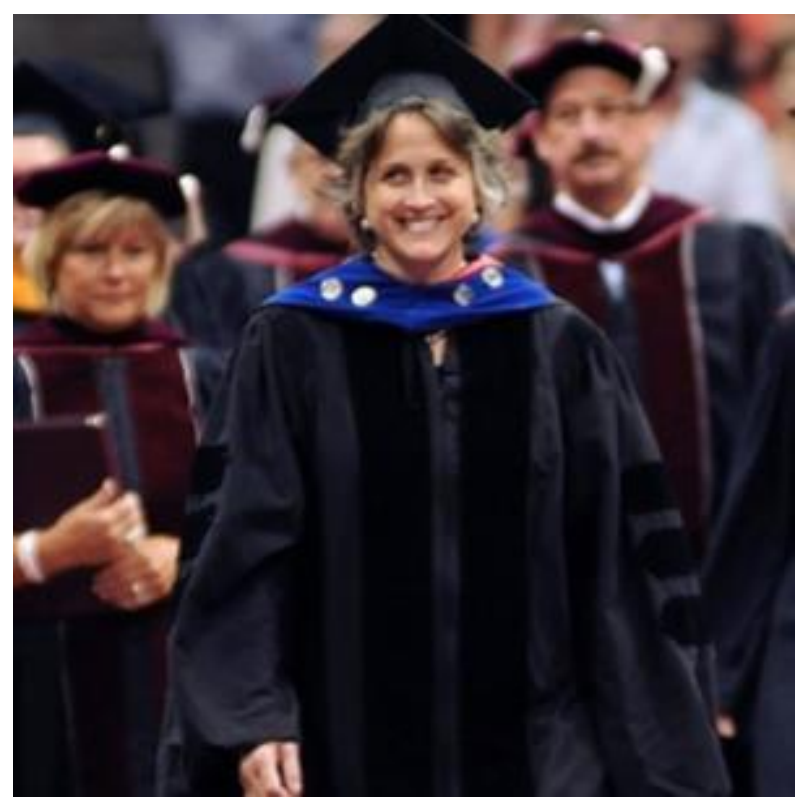

When Dr. Rachelle Darabi arrived on campus in late September of 2008, the new Associate Provost for Student Development and Public Affairs brought a fresh vision for solidifying MSU's Public Affairs Mission. Many on campus could name the pillars of the missionethical leadership, cultural competence, and community engagement - but were not sure what all that meant, and many didn't really care. Today, thanks in large part to her leadership, the mission is in many ways fully integrated into the fabric of the institution. Though she would be quick to say she didn't make those changes without help, perhaps her leadership in integrating the mission is the most significant of her accomplishments at MSU.

Specific changes/additions Dr. Darabi deserves credit for spearheading include transforming the Academic Development Center to the Faculty Center for Teaching and Learning (and hiring instructional designers to support it) and the Writing Center into the Bear CLAW (Center for Learning and Writing) with a much larger mission, including subject-area tutoring and peer mentors as well as workshops to improve student success. She broadened the scope of the Academic Advisement Center, now the Academic Advising and Transfer Center (emphasizing more help for transfer students) and First-Year Programs, now The Center for Academic Success and Transition (adding support for first-generation students). Dr. Darabi also helped create the Jump START Program ("Summer Transition and Academic Readiness Training," working with students at risk to grow their retention rate from about $25 \%$ to 75 and even $80 \%$ ), the Peace Corps Prep Program (to prepare students for international fieldwork and Peace Corps service), and the Bear Pantry (a food bank for hungry students). 
Missouri State's Journal of Public Affairs had lain dormant for years, and Dr. Darabi recognized its potential as a voice for our mission. She researched its history and resurrected it with significant changes: as an electronic publication with themed issues and contributions from writers outside Missouri State University. She sought and received a partnership with the American Democracy Project, thereby getting help with establishing a first-class editorial board. Under her leadership as Executive Editor, the eJournal of Public Affairs has flourished.

These are a few of Dr. Rachelle Darabi's accomplishments at Missouri State, but no tribute would be complete without mentioning what a joy it has been to work with her. She has led us gently and by example, and always with a dose of fun. Having served as Interim Associate Provost while we searched for the right person to fill the job, I was privileged to work closely with Rachelle for the first several months she was on campus, and again after I retired as I filled in as managing editor for the eJournal. It was easy to work with her-and it always seemed like I was working with her, not for her-for at all times she was in the trenches working as hard as any of us. I was impressed with her vision for MSU's mission and the fresh ideas she brought for putting it into practice. But even more I was impressed with her attitude and approach, with her ability to make the load seem light. Her eyes literally sparkle, letting her personality shine through. It doesn't hurt that she also likes barbeque and fun field trips as much as I do. Her retirement is MSU's loss, but I hope now I can spend more time with my friend. For us retirees, every day is a snow day, and I know Rachelle will continue to fill her days with fun and exciting adventures. Thanks for all you've done for Missouri State University - and happy trails, Rachelle!

Michael Frizell, Director of Student Learning Services, Missouri State University

When I heard I was going to have a new supervisor, and I was skeptical.

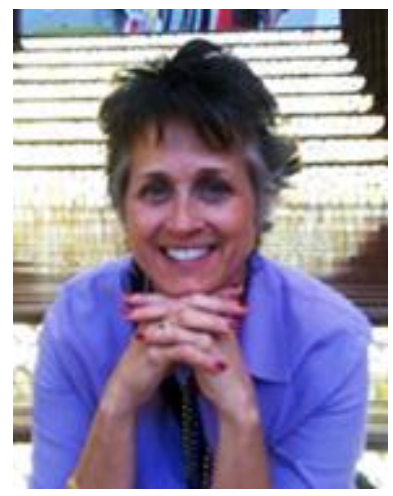

Four years earlier, I moved from a faculty line in the now-defunct Collegiate Reading and Learning Program to a staff position as director of the Writing Center during a time of change at Missouri State University. We dropped the "Southwest" from our name, enhanced our admission requirements, and dissolved the University College. I reported to a vice president - I don't remember what he was VP of, to be honest. He was jovial enough, but his handshakes were a crush designed to show dominance. His advice?

"Don’t go over budget, okay?"

The bulk of my interactions were with student workers, clients of the Center, and the faculty advisory board I created to inform our work. If this autonomy sounds perfect to you, realize I was holding the Center together through sheer force of will. 
Dr. Rachelle Darabi filled the new position of Associate Provost for Student Development and Public Affairs, a conglomeration of former University College departments and offices designed to fulfill MSU's public affairs mission.

Our first meeting was in my office, a former galley kitchen used by the Hospitality department. They left the 70s era cabinets. We exchanged pleasantries about our children and how she was settling in. She leaned back.

"You used to teach study skills. Did you enjoy that?'

"I'd like to get back to it."

“Good. How would you like to direct a Supplemental Instruction program?'

"Never heard of it."

Dr. Darabi explained that it was an academic support service created by the University of Missouri - Kansas City to help students succeed in high-enrollment courses. She added that she had ten faculty on board for the spring. I agreed. She told me to hire ten student workers without knowing anything about their roles, go to supervisor training in January (it was October), and then train them the following week. She trusted me to figure out the logistics.

Her enthusiasm was infectious. And trust? After speaking with my colleagues, I discovered she wasn't reinventing the wheel. She was helping the wheel roll better.

Inspired, I interviewed potential employees, telling them, "I don't know what SI is, but you'll love it! Are you in?" I mimicked her ardent enthusiasm, and it worked. Within a year, the SI supported 40 courses and served thousands of students.

Dr. Darabi leveraged this success to form a committee that expanded my center and created the Bear CLAW (Center for Learning and Writing). This modern learning commons included STEM tutoring, course mentoring, learning enhancement coaches, and more.

And that was only her first year of a twelve-year stint.

The dean who hired me 20 years ago told me, "Make yourself indispensable. Find ways to get in front of the right people." And I tried, my voice often the only voice in a room full of decisionmakers who regarded student support services as a drain on funds. Now? I didn't need to conspire to sell my ideas. I had Dr. Darabi. She was in the rooms with the right people, armed with boundless energy, and she had plans. She saw the vacuum in student support and the potential to create something new. Something better.

And she did it with a smile. 